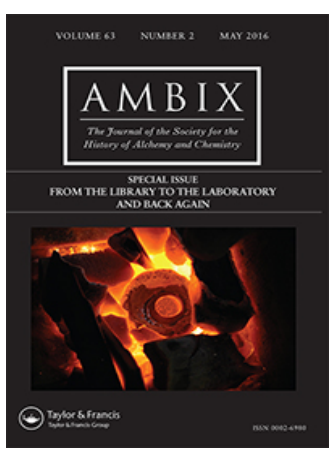

Ambix

\title{
Understanding Texts with the Help of Experimentation: The Example of Cupellation in Arabic Scientific Literature
}

\section{Sébastien Moureau \& Nicolas Thomas}

To cite this article: Sébastien Moureau \& Nicolas Thomas (2016) Understanding Texts with the Help of Experimentation: The Example of Cupellation in Arabic Scientific Literature, Ambix, 63:2, 98-117, DOI: $10.1080 / 00026980.2016 .1216691$

To link to this article: http://dx.doi.org/10.1080/00026980.2016.1216691

\section{曲 Published online: 29 Sep 2016.}

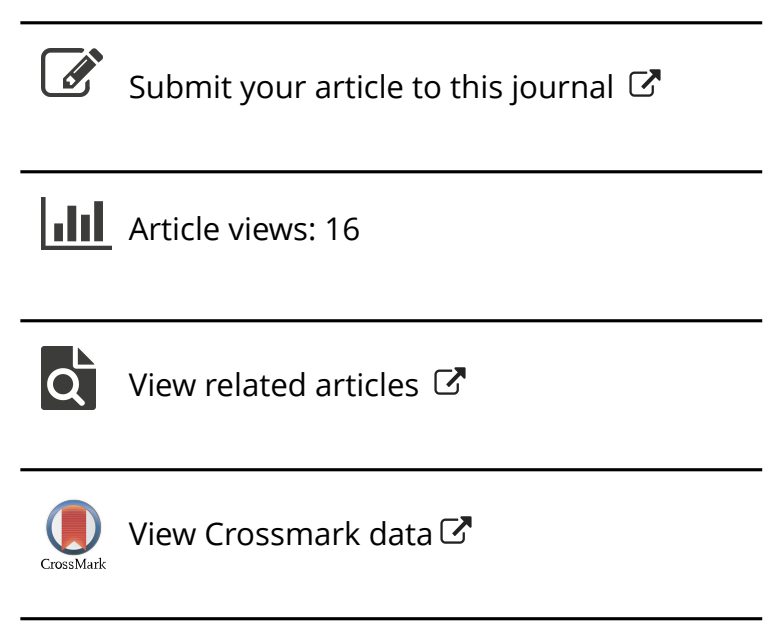




\title{
Understanding Texts with the Help of Experimentation: The Example of Cupellation in Arabic Scientific Literature
}

\author{
SÉbastien Moureau' and Nicolas Thomas ${ }^{2}$ \\ ${ }^{1}$ The Warburg Institute, London, UK \\ ${ }^{2}$ Institut National de Recherches Archéologiques Préventives (INRAP), \\ Passy, France
}

The article aims to show how experimentation can help us understand historical texts, by focusing on the specific case of cupellation in Arabic scientific literature. It also provides new information about cupellation in the Arab-Muslim Middle Ages. The article consists of translations of three of the most detailed accounts of cupellation: Hamdānī's Kitāb al-jawharatayn al-'atīqatayn (first half of the fourth/tenth century), Maslama b. Qāsim al-Qurțubī, Rutbat al-ḥakimm (339-342/950-953), and Manșūr b. Ba'ra, Kitāb kashf al-asrār al-'ilmiyya bi-dàr al-darb al-mișriyya (615-635/1218-1238). These are accompanied by commentaries based on a series of experiments carried out in the course of archaeological research on cupellation, which are here used to shed new light on the medieval texts and resolve several problems in interpreting them.

\section{Introduction}

Reading a text with understanding, whatever the language, epoch, or field, always requires prior knowledge. ${ }^{\mathrm{I}}$ This prior knowledge is polymorphic, ranging from language skills to historical knowledge, and its level varies according to the nature of the text-for instance, whether it constitutes a handbook, a recipe collection, and so forth. In order to acquire this prior knowledge, various tools and methods are available, among which the use of documents (and experts) is the most usual. When reading historical scientific and technical texts, this prior

\footnotetext{
The claim that knowledge of one thing always requires prior knowledge raises the problem of the argument of regress, but we will not enter this philosophical debate in this article.
} 
knowledge is often very hard to acquire, being more polymorphic than Proteus himself. Researchers can access various sorts of documents in order to understand such technical writings, including other texts, both historical and contemporary, and archaeological remains. However, when dealing with technical writings, these sources are often insufficient for a full understanding of what the authors meant. For researchers who want to go further in understanding texts of this kind, experimentation provides a valuable tool. This tool may be used to answer questions raised when analysing documents (i.e. conducting an experiment in order to answer a precise question), but also in a heuristic way, by using the experience acquired from previous experiments, which is how it is used in this article. Indeed, reproducing the gestures of a process, feeling and experiencing its sensations (not only sight, but also the other senses), or alternatively, when practical contingencies make it impossible to attempt oneself, ${ }^{2}$ talking with a person who has performed the practice, is an appropriate way of filling the gaps.

This article is one result of the collaboration between a philologist and an archaeologist who has conducted more than one hundred cupellation experiments. ${ }^{3}$ Besides offering an example of such collaboration, it is intended to show how such experiments can contribute towards understanding texts whose meaning cannot otherwise be discerned. Our second aim is to offer new information on the study of cupellation in the Arab-Muslim Middle Ages, by comparing instructions on cupellation from three different Arabic treatises and examining these in light of experimental evidence. The body of the article consists of translated texts accompanied by an "experimental commentary": that is to say, comments that expand on the technical content of the text in light of our own observations. Together, text and commentary provide a tool that will allow readers to better grasp the process of reading texts with the help of practical experimentation.

\section{Cupellation}

Cupellation is a technique used to purify gold and silver: an alloy of gold or silver with other metals can be separated when melted due to the more rapid oxidation of the other metals. ${ }^{4}$ This process is based on the fact that, when heated, gold and

2 Conducting experiments is difficult, sometimes dangerous, and often expensive; it requires knowledge, experience, and funding.

3 Nicolas Thomas has carried out hundreds of experiments on cupellation for fifteen years in the context of his archaeological research. The aim of these experiments was first to produce experimental artefacts similar to archaeological finds, particularly cupels of the kind used for assaying in muffle furnaces in the late Middle Ages. More recently, Thomas' experiments on cupellation have been aimed at understanding the practice, "know-how," and implications of the oxidative fusion with fire upon molten metal. On his previous cupellation experiments, see Florian Téreygeol and Nicolas Thomas, "La coupellation des alliages cuivre-argent: approche expérimentale de l'essai d'argent par voie sèche," Revue d'Archéométrie 27 (2003): I7I-8I.

4 For general information on the cupellation process, see Robert J. Forbes, Metallurgy in Antiquity: A Notebook for Archaeologists and Technologists (Leiden: Brill, I950), I 58-60, 205-I4; Andrew Oddy, "Assaying in Antiquity," Gold Bulletin I6 (1983): 53-5; Justine Bayley, "Processes in Precious Metal," in Archaeological Sciences 1989: Proceedings of a Conference on the Application of Scientific Techniques to Archaeology, Bradford, September 1989, ed. Paul Budd, B. Chapman, C. Jackson, R. Janaway, and B. Ottaway (Oxford: Oxbow, I99I), I 25-3 I; Justine Bayley and Kerstin Eckstein, "Silver Refining: Production, Recycling, Assaying," in Archaeological Sciences 1995, ed. 


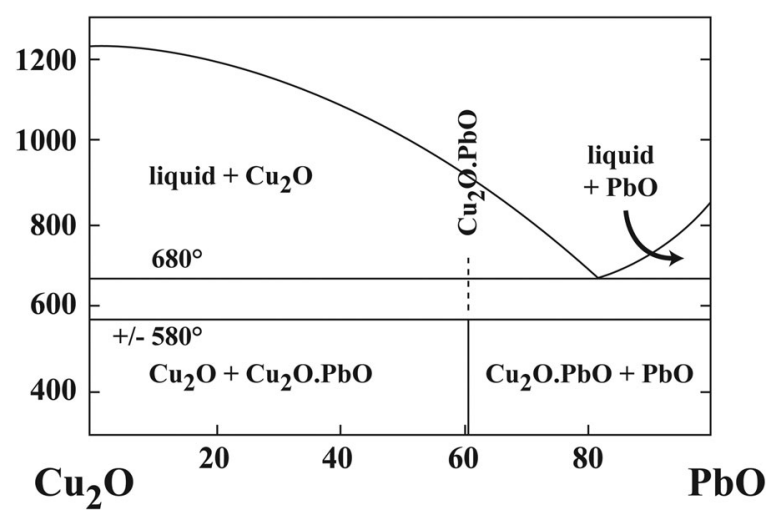

FIGURE 1 Phase diagram of copper and lead oxides. Data from Erich Gebhard and Walter Obrowski, “Über den Aufbau des Systems Kupfer-Blei-Sauerstoff," Z. Metallkunde 45 (1954): 332-8.

silver do not oxidise, while the other metals-copper, tin, and particularly leadoxidise quickly. Cupellation is performed by adding lead to impure gold or silver: lead helps the process since litharge (lead oxide, $\mathrm{PbO}$ ) increases the fusibility of the other metal oxides (Figure I), ${ }^{5}$ does not react with silver or gold, and remains separate from them. Since the process requires the oxidation of the metals, it implies an oxidising atmosphere, a high temperature, and a high surface-to-volume ratio of the molten metal. Finally, cupellation requires a way of removing the metal oxides. Cupellation is used for both refining and assaying the metals. The technique cannot be used to separate gold from silver, which requires another process, cementation. ${ }^{6}$

Many documents on cupellation are available, in addition to the contemporary scientific studies cited above (note 4 ). Technical handbooks dating from the sixteenth to the nineteenth century describe techniques which sound quite close, if not identical, to medieval processes, although one must be extremely careful not to apply anachronistic readings to earlier texts. ${ }^{7}$ Medieval Latin

Continued

Anthony Sinclair, Elizabeth Slater, and John Gowlett (Oxford: Oxbow, I997), I07-II; Justine Bayley, "Medieval Precious Metal Refining: Archaeology and Contemporary Texts Compared," in Archaeology, History and Science: Integrating Approaches to Ancient Materials, ed. Marcos Martinón-Torres and Thilo Rehren (Walnut Creek: Left Coast Press, 2008), I 3 I-50; Marcos Martinón-Torres, Nicolas Thomas, Thilo Rehren, and Aude Mongiatti, "Some Problems and Potentials of the Study of Cupellation Remains: The Case of Post-Medieval Montbéliard, France,” ArchéoSciences, Revue d'Archéométrie 32 (2008): 59-70; Marcos Martinón-Torres, Thilo Rehren, Nicolas Thomas, and Aude Mongiatti, "Identifying Materials, Recipes and Choices: Some Suggestions for the Study of Archaeological Cupels," in Archaeometallurgy in Europe 2007: Selected Papers from 2nd International Conference, Aquileia, Italy, 17-21 June 2007, ed. Alessandra Giumlia-Mair (Milan: Associazione Italiana di Metallurgia, 2009), $435-45$.

5 Erich Gebhardt and Walter Obrowski, "Über den Aufbau des Systems Kupfer-Blei-Sauerstoff," Zeitschrift für Metallkunde 45 (I954): 332-4I.

6 On this process, see Nicolas Thomas, "Prendre de l'acier pour de l'or," in Hypothèses 2005 (Paris: Publications de la Sorbonne, 2006), I75-86.

7 For instance: Francesco Balducci Pegolotti, Pratica della mercatura, I335-I343, ed. Allan Evans (Cambridge, MA: Medieval Academy of America, I936), 339-42; Vanocchio Biringuccio, De la pirotechnia libri X (Venice: Venturino 
technical texts also provide very valuable information on the processes described in Arabic texts. ${ }^{8}$

There is also extensive archaeological evidence of cupellation, which substantially increases our understanding of the texts. ${ }^{9}$ These remains show early traces of cupellation, confirming it to be a very ancient process. One of the earliest examples dates from the tenth century BC: a furnace found in Argos, which seems to have been used for cupellation. ${ }^{\text {IO }}$ A workshop in which cupellation and cementation appear to have been performed has been found in the excavations in Sardis (sixth century $\mathrm{BC}),{ }^{\mathrm{II}}$ and the process was also used in the well known silver mines of the Laurion (sixth-fifth centuries BC). ${ }^{\mathrm{I} 2}$ Textual hints of cupellation can be found as early as the Old Testament book of Jeremiah, ${ }^{{ }^{3} 3}$ the Arthaśāstra attributed to Kautilia (part of which could date back to the third century $\mathrm{BC}$, although the dating of the text is quite uncertain), Diodorus Siculus's Bibliotheca historica (first century BC, quoting

\section{Continued}

Rossinello ad instantia di Curtio Navo, I 540), 45 r-47r, 53v-59r; Georgius Agricola, De re metallica libri XII (Basel: Froben et Episcopius, I 556), I74-207 and 369-92, English translation: Georgius Agricola, De Re Metallica, Translated from the First Latin Edition of 1556, trans. Herbert Hoover and Lou Henry Hoover (New York: Dover Publications, 1950), French translation: Georgius Agricola, De re metallica, traduit de l'édition latine de 1556, trans. Albert France-Lanord, 2nd ed. (Thionville: G. Klopp, I992); Lazarus Ercker, Beschreibung der allervornehmsten mineralischen Erze und Bergwerksarten, in Lazarus Ercker's Treatise on Ores and Assaying, Translated from the German Edition of 1580, ed. and trans. Anneliese Grünhaldt Sisco and Cyril Stanley Smith (Chicago: University of Chicago Press, I95I), 9-82; Anonymous, Probierbüchlein, in Bergwerk- und Probierbüchlein. A Translation from the German of the Bergbüchlein, a Sixteenth-Century Book on Mining Geology, and of the Probierbüchlein, a Sixteenth-Century Work on Assaying, ed. and trans. Anneliese Grünhaldt Sisco and Cyril Stanley Smith (New York: American Institute of Mining and Metallurgical Engineers, 1949); Balthasar-Georges Sage, L'art d'essayer l'or et l'argent (Paris: Imprimerie de Monsieur, I780); Ferdinand Hoefer, Histoire de la chimie, 2nd ed., 2 vols. (Paris: Firmin-Didot frères, I 866-I 869), vol. I, I I 5 and sqq.; Carl Schnabel, Handbuch der Metallhüttenkunde (Berlin: Springer, I 894-96), English translation: Handbook of Metallurgy. Vol. 1. Copper, Lead, Silver, Gold, trans. Henry Louis (London: Macmillan and Co., I 898), 566-96.

8 For instance, Theophilus's Diversarum artium schedula, and Pseudo-Geber's Summa perfectionis, as quoted below. See Ricardo Córdoba de la Llave, Ciencia y técnica monetarias en la España bajomedieval (Madrid: Fundacion Juanelo Turriano, 2009).

9 Justine Bayley, "Innovation in Later Medieval Urban Metalworking," Historical Metallurgy 30 (I996): 67-7I; Christopher McLees, "Itinerant Craftsmen, Permanent Smithies and the Archbishop's Mint: The Character and Context of Metalworking in Medieval Trondheim," Historical Metallurgy 30 (I996): I2 I-35; Thilo Rehren and Kerstin Kraus, "Cupel and Crucible: The Refining of Debased Silver in the Colonia Ulpia Traiana, Xanten," Journal of Roman Archaeology I 2 (1999): 263-72; Anders Söderberg, "Metallurgic Ceramics as a Key to Viking Age Workshop Organisation," Journal of Nordic Archaeological Science I4 (2004): II 5-24; Nicolas Thomas, Marcos Martinón-Torres, Corinne Goy, and Thilo Rehren, "La fouille archéologique du quartier Velotte à Montbéliard : Nouvelles données sur des opérations de chimie oubliées," Bulletin de la Société d'Émulation de Montbéliard I 29 (2006): 44I-65; and Gerald Stefke, "Die Einführung der Kupellenprobe (Probe auf der Kapelle) als moderne Probiertechnik für Silber in den mitteleuropäischen Münzstätten des Spätmittelalters,” in Interdisziplinäre Tagung zur Geschichte der neuzeitlichen Metallgeldproduktion, Tagung in Stolberg (Harz) im April 2006, ed. Reiner Cunz et al. (Braunschweig: Braunschweigische Wissenschaftliche Gesellschaft, 2008), 4I I-64.

Io Paul Courbin, "Stratigraphie et stratigraphie: Méthodes et perspectives," in Études archéologiques, ed. Paul Courbin (Paris: SEVPEN, I963), 98-100.

I Andrew Ramage and Paul T. Craddock, King Croesus' Gold: Excavations at Sardis and the History of Gold Refining (London: British Museum Press, 2000), passim.

${ }^{12}$ Édouard Ardaillon, Les mines du Laurion dans l'Antiquité, Bibliothèque des Écoles françaises d'Athènes et de Rome 77 (Paris: A. Fontemoing, I 897), 75-89; Hélène F. Mussche, "Recent Excavations in Thorikos," Acta Classica I3 (1970): I25-36; Constantin E. Conophagos, Le Laurium antique et la technique grecque de la production de l'argent (Athens: Ekdotike hellados, I980), 305-30, and "La technique de la coupellation des Grecs anciens au Laurium," in Archaeometry. Proceedings of the 25th International Symposium, Athens 1986, ed. Yannis Maniatis (Amsterdam: Elsevier, 1989), 27I-89; Olivier Picard, "La découverte des gisements du Laurion et les débuts de la chouette," Revue belge de numismatique et de sigillographie I47 (200I): I-IO.

${ }^{13}$ Jer. 6:27-30. 
Agatharchides, second century BC), ${ }^{\mathrm{I} 4}$ Pliny's Historia naturalis (first century AD), ${ }^{\mathrm{I}}$ and the Papyrus $X$ of Leiden (fourth century AD). ${ }^{16}$ As for the Latin medieval world, there are many precise textual descriptions of cupellation: Theophilus's Diversarum artium schedula (beginning of the twelfth century), ${ }^{17}$ the Dialogus de Scaccario (twelfth century), ${ }^{18}$ Pseudo-Geber's Summa perfectionis (end of the thirteenth century), ${ }^{19}$ the treatise on minting coins in MS 46 of the Real Colegiata de San Isidoro de León (fourteenth century), ${ }^{20}$ and Guillaume Sedacer's Sedacina (late fourteenth century). ${ }^{2 \mathrm{I}}$ Cupellation was still in use in the ninteenth and twentieth centuries, ${ }^{22}$ but it has now been replaced in most cases by more precise techniques, especially for low-silver content alloys.

Cupellation was carried out using a special crucible called a cupel. This cupel was made of crushed bones or vegetable ashes, and sometimes additional substances, moistened with a bit of water and pressed into a particular shape, or simply pressed into another pot, such as a crucible, or even, for large quantities, pressed into the bottom of a basin inside a large furnace. The ashes must be allowed to dry completely before the cupel is used. The material of the cupel is sufficiently porous to absorb the litharge and the other metal oxides, but not porous enough to absorb the metal. At the end of the process the cupel has absorbed the litharge, and a silver button remains in the centre of the cupel (Figures 2 and 3 ). Lead is added to the metal (gold or silver) in a proportion dependent upon the gold or silver concentration of the alloy. The process must often be repeated: the more impure the silver or gold, the more repetitions of the process are required. From the fifteenth century, when assaying or refining small amounts of metal, craftsmen used a special device called a muffle, a kind of small cage which separates the metal from the charcoal without impeding the heating, and which facilitates the creation of a stable oxidising atmosphere. In large-scale processes, the cupel cannot absorb all the litharge, which must be removed by other means, for example, by using a gutter that is opened at some point in the process.

${ }^{14}$ Diodorus Siculus, Bibliotheca historica, Book 3, chaps. I I-4 (esp. I4).

${ }_{5}$ Pliny, Historia naturalis, bk. 33, chap. 6, sect. 3 I, 95; Kenneth Claude Bailey, The Elder Pliny's Chapters on Chemical Subjects, 2 vols. (London: E. Arnold \& Co., I929-1932), vol. I, I Iо-I.

${ }^{16}$ Robert Halleux, ed., Papyrus de Leyde. Papyrus de Stockholm. Fragments de recettes, trans. Robert Halleux (Paris: Les Belles Lettres, I98I), 9г.

${ }_{17}$ Theophilus, Diversarum artium schedula, bk. 3, chaps. 23 and 68; Charles Reginald Dodwell, ed., Theophilus, The Various Arts, De diversis artibus (Oxford: Clarendon Press, I961), 74-5, I27-8.

${ }^{18}$ Charles Johnson, ed., Dialogus de Scaccario: The Course of the Exchequer, by Richard Fitz Nigel, and Constitutio Domus Regis: The Establishment of the Royal Household, trans. Charles Johnson (Ist ed. 1950), (Oxford: Clarendon Press, I983), passim.

19 William R. Newman, The Summa Perfectionis of Pseudo-Geber: A Critical Edition, Translation and Study (Leiden: Brill, I99I), 590 and sqq.

20 Betsabé Caunedo del Potro and Ricardo Córdoba de la Llave, El Arte del alguarismo. Un libro castellano de aritmética comercial y de ensayo de moneda del siglo XIV: Ms. 46 de la Real Colegiata de San Isidoro de León (Salamanca: Junta de Castilla y León, 2000), passim.

${ }_{21}$ Sedacer, La Sedacina ou l'CEvre au crible : l'alchimie de Guillaume Sedacer, carme catalan de la fin du XIV ${ }^{e}$ siècle, ed. and trans. Pascale Barthélémy (Paris: S.É.H.A.-ARCHÈ, 2002), I33.

22 See for instance Louis Troost, Précis de chimie, 3 rd ed. (Paris: Victor Masson et fils, I870), I92, I97-8, 200, and 21 7; Alfred Riche and Edmond Gélis, L'art de l'essayeur (Paris: J.-B. Baillière, I888), and Schnabel, Handbook of Metallurgy. Vol. 1, 566-96. 

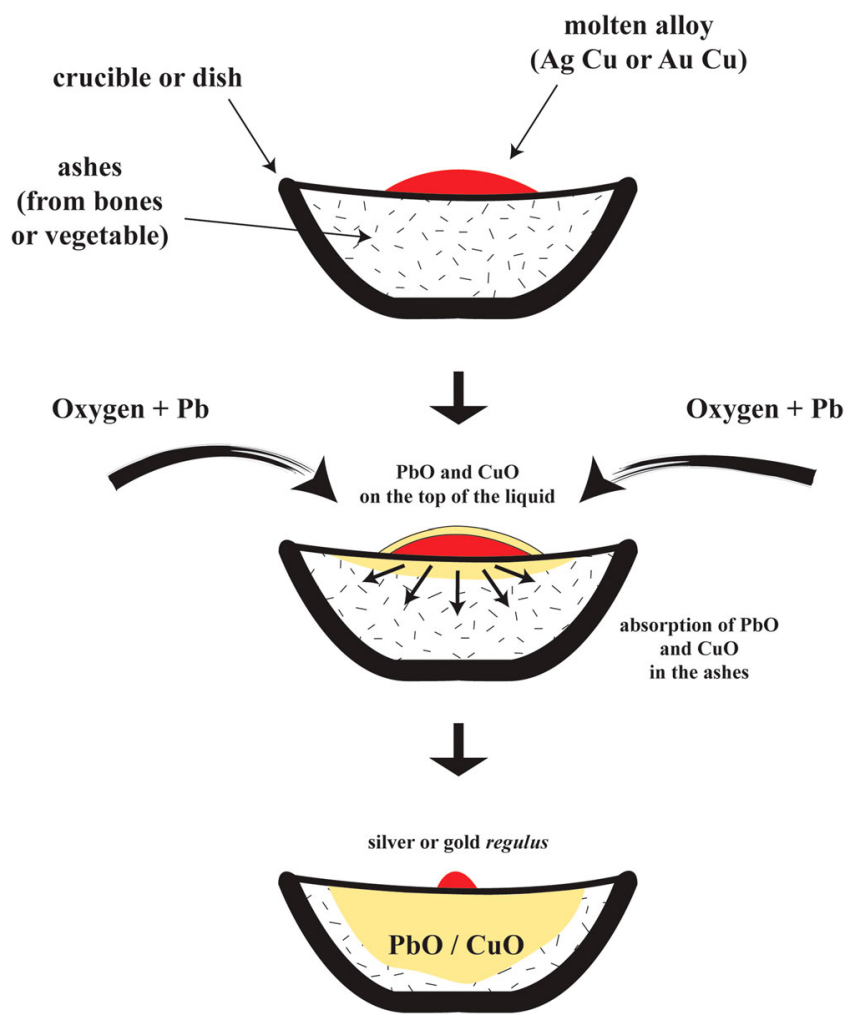

FIGURE 2 Crucible filled with ashes before, during, and after the cupellation process. (C) Nicolas Thomas.

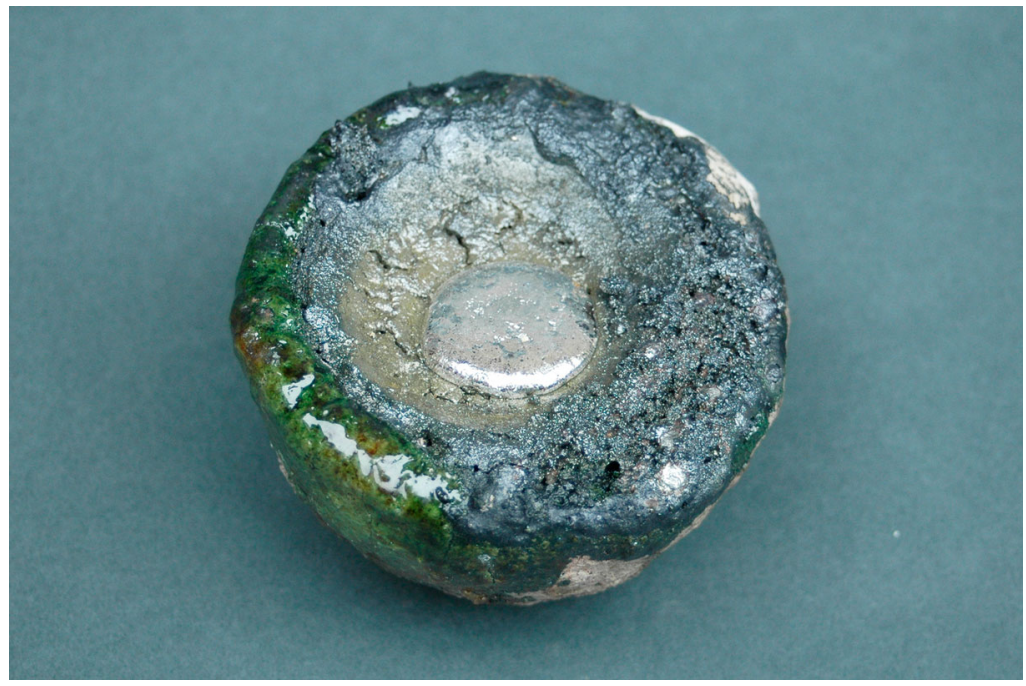

FIGURE 3 The silver button at the bottom of an ash-filled crucible after the cupellation process. (C) Nicolas Thomas. 


\section{Experimentatio ancilla philologiae}

Although cupellation is described multiple times in the Arabic literature, only a few descriptions are detailed. The passages analysed in this article do not form an exhaustive list of the texts on cupellation, but only a representative sample of those containing the most precise descriptions: Hamdānī's Kitāb al-jawharatayn al-'atīqatayn (first half of the fourth/tenth century), Maslama b. Qāsim al-Qurțubī's Rutbat al-ḥakìm (339-342/950-953), and Manșūr b. Ba'ra's Kitāb kashf al-asrār al-'ilmiyya bi-dār al-darb al-mișriyya (6 I 5-635/I 2 I 8-I 238 ). ${ }^{23}$

Before providing the translated passages, a few preliminary remarks are necessary regarding most of the Arabic texts on cupellation. As would be expected, no text mentions the muffle, which appears only later. Most texts explicitly mention that charcoal is put on the cupel, and that a specific type of bellows is used to blow directly on the silver. These particular bellows are called in Arabic rawbās, or rawbāsh or rawbās: ${ }^{24}$ they are bellows that blow downwards, directly onto the cupel from above, as in a forge. Ibn Ba'ra describes them clearly: "The rawbāsh is a bellows of which the head is upside down; its blow comes out of its opening downwards into the middle of the crucible." 25 In some passages, the rawbās seems to be a part of the bellows, maybe the opening turned upside down. Experimentation proves that the blow of the bellows is sufficient both to provide a high temperature and to oxidise the lead (Figures 4 and 5 ). ${ }^{26}$

23 Almost all the commonly known and detailed passages are here. However, two important texts have been left out: (I) The book entitled al-Dawha al-mushtabika fì dawābit dār al-sikka (The Entangled Tree in the Rules of the Mint Workshop), written by Abū al-Hasan 'Alī b. Yūsuf al-Hakīm al-Kūmī in Fez during the reign of the Mārinid sultan Abū Fāris 'Abd al-'Azīz (768-774/I366-I 372 ) has not been quoted. Since this treatise is a compendium of quotations on theoretical and technical aspects of coinage (including some philosophical considerations), the passage on cupellation (in chapter 3 ) is actually a verbatim quotation from Maslama b. Qāsim's Rutbat al-hakìm. There are only slight differences, perhaps due to the textual transmission. The text is edited in Abū al-Hasan 'Alī b. Yūsuf al-Hakīm al-Kūmī, Al-Dawha al-mushtabika fì dawābit dār al-sikka, ed. Husayn Mu’nis, Ṣahị̂fat Ma'had al-dirāsāt al-islāmiyya fì Madrīd 6, I-2 (Madrid: Ma‘had al-dirāsāt al-islāmiyya, I958). Extracts have been translated into French in Khaled Ben Romdhane, "Contribution à l'histoire monétaire du Maghreb médiéval: Monnaies de l'Ifriqiya de la conquête arabe à la chute des Hafsides (fin du $\mathrm{I}^{\mathrm{er}}$-milieu du X $\mathrm{X}^{\mathrm{e}}$ s. H./VII ${ }^{\mathrm{e}}$-milieu du XVI ${ }^{\mathrm{e}}$ s.)" (Ph.D. dissertation, Université de Paris 4, I997), and by Viala in Joseph-Dominique Brethes, Contribution à l'histoire du Maroc par les recherches numismatiques (Casablanca: Les Annales marocaines, I939), 253-67. On the author, see Mohamed b. A. Benchekroun, La vie intellectuelle marocaine sous les Mérinides et les Watțāsides (XIII ${ }^{e}, X I V^{e}, X V^{e}, X V I^{e}$ siècles) (Rabāṭ: [s.n.], I974), $2 \mathrm{I} 3$. (2) The description in Hamdūn al-Jaznā'î’s Al-aṣdāf al-munfaḍda 'an ahkām 'ilm șan'at al-dīnār wa-al-fiḍda (The Scattered Pearls on the Opinions of the Science of the Art of the Dīnār and of Silver), a treatise on coin minting, has not been included in this article because of its late composition (late sixteenth century, between 997/I 589 and IOI2/1603, in Morocco). This text has been edited in Khaled Ben Romdhane and Abdelhakim Gafsi, "Al-aṣdāf al-munfaḍa 'an aḥkām 'ilm șan'at al-dīnār wa-al-fiḍ̣a li-Abī al-'Abbās Aḥmad al-mad'ū Hamdūn al-Jaznā'î / Traité de technique monétaire (XVII s.). Al-așdāf al-munfaḍda," in Mélanges Professeur Robert Mantran, ed. Abdeljelil Temimi (Zaghouan: Centre d'études et de recherches ottomanes, morisques, de documentation et d'information, I988), 29-72. On this treatise, see Khaled Ben Romdhane, "Traité inédit de technique monétaire," Revue numismatique 6 (1988): 207-26, containing some extracts translated into French.

${ }^{24}$ Or $r \bar{u} b \bar{a} s, r \bar{u} b \bar{a} s h, r \bar{u} b \bar{a} s$. The word $r a w b \bar{a} s$ was sufficiently common in the twelfth and thirteenth centuries to be used as a metaphor in an anecdote found in Ibn Manẓūr's (630-7I I/I233-I3 I I or I3 I2) Mukhtașar Ta'rīkh Dimashq: "He said: 'You are right, I am the rawbās of people from Syria to Egypt.' Then he said: 'Do you know what the rawbās is?' I said: 'No.' He said: 'It is the instrument by which one separates what is good in silver from its impurities.'” Ibn Manz̄ūr et al., Mukhtașar Ta'rīkh Dimashq, 29 vols. (Damascus: Dār al-fikr li-al-țabā'a wa-al-tawzī‘ wa-al-nashr, I984), vol. 21, 333 .

25 Manșūr b. Ba'ra al-Dhahabī al-Kāmilī, Kashf al-asrār, 87 (without the vocalisation and the punctuation): ". وصفة الروباش منفاخ مكبوب الرأس يخرج ريحه من فمه إلى أسفل في وسط البوط "

26 There is no compelling need for the muffle in cupellation. The muffle is used to afford greater precision when assaying. 


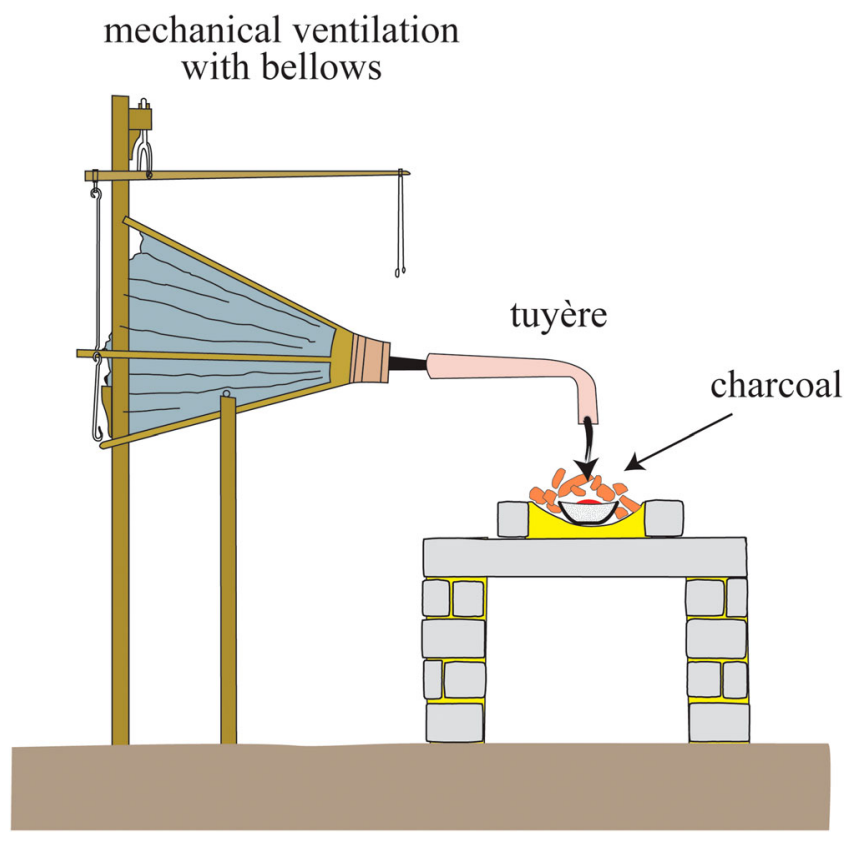

FIGURE 4 Cupellation process, with bellows blowing on the crucible or cupel from above. (C) Nicolas Thomas.

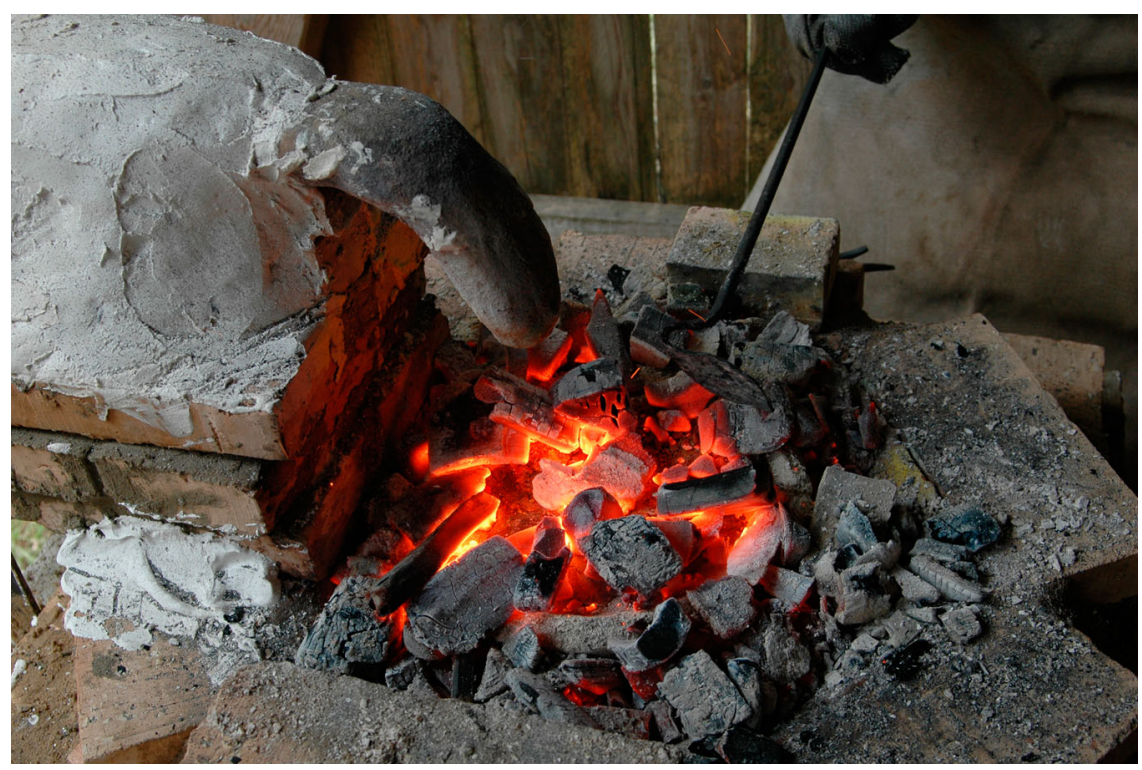

FIGURE 5 Cupellation process, with bellows blowing on the ash-filled crucible from above (the crucible is under the charcoal). (C) Nicolas Thomas.

We provide translations below of the three accounts of cupellation mentioned above, each being preceded by a short introduction to the treatise in question. Each includes comments, where needed, that demonstrate the contribution that 
conducting experiments has made to our understanding of the texts. ${ }^{27}$ For the sake of clarity, the chronological order has been inverted, since the shortest and easiest description is in Ibn Ba'ra's text, and the most complicated and detailed in Hamdānī's.

I. Manșūr b. Ba'ra, Kitāb kashf al-asrār al-'ilmiyya bi-dār al-darb al-mișriyya (6I 5-635/I 2I 8-I 238$)^{28}$

The Kitāb kashf al-asrār al-'ilmiyya bi-dār al-darb al-mișriyya (Book of the Unveiling of the Scientific Secrets of the Egyptian/Cairo Workshop for Minting Coins) was composed by Manșūr Ibn Ba'ra al-Dhahabī al-Kāmilī in Cairo during the reign of the Ayyubid sultan al-Kāmil (6I5-635/I2I8-I238). It is a technical treatise about coin minting, providing numerous descriptions. Cupellation is explained mainly in chapter nine on the purification of silver by the means of lead (tafșiya al-fidda bi-al-rașāṣ).

Ibn Ba'ra describes cupellation as follows: ${ }^{29}$

As for the purification of silver (here is the process).

[1] You must take the silver, put it into a crucible made of a mixture of half slaked lime and half sieved ashes moistened with a bit of water. [2] Put lead with the silver: if the weight of the silver is 300 dirhams, put one pound [ ratl] of lead. Then put charcoal on it, and blow on it continuously (or adequately) with the purification bellows [rawbāsh]. [3] If the silver rotates, one puts wood on it. The blow remains continuous until the lead and the copper are burnt and the silver appears pure [talgham]; then one removes it (from the cupel) and hammers it on the anvil. [4] Then one heats it and twists it when it is hot; if it does not tear, it is pure, but if it does not bear twisting and tears, there is lead in it. (Pure silver) bears twisting when it is hot and does not tear.

[1] Ibn Ba'ra does not mention that the cupel must be dried before being used or it will crack when heated.

[2] In the eleventh and twelfth centuries in Egypt (Fātimid period), and probably also in the thirteenth century, when Ibn Ba'ra wrote his treatise, the Egyptian pound was equivalent to I4O or I44 dirhams; $3^{30}$ in this case, one adds less lead than half the weight of silver, which is a very low ratio and implies that the silver was almost completely pure or that the alloy did not contain a high proportion of copper (which requires a lot of lead to be removed). ${ }^{3 \mathrm{I}}$

[3] This passage gives us the opportunity to show one of the most exemplary contributions of experiments to philology. The Arabic sentence "idhā dārat al-fidda ja'ala 'alay-hā hataban" is literally translated here. Martin Levey, who translated the entire treatise into English, was puzzled by this passage and translated it: "if the silver is desired, wood for burning is put on it;" ${ }^{32}$ he probably assumed a corruption of the text and read something like idh aradta (اذ اردت ) instead of $i d h \bar{a}$ dàrat (اذارت (ارت), which is, at first glance, a reasonable proposal. However, experimentation allows us to confirm that the reading idha darat is correct: when one does a cupellation, the metal oxides actually rotate in the cupel, which gives the impression that the silver itself is rotating (Figure 6). ${ }^{33}$

[4] This last passage describes a mechanical test of the silver. Silver is the most ductile metal after gold, and an alloy of silver and lead is much more brittle than pure silver; it will tear if twisted when heated.

27 The translation is on the left, and our commentary on the right, each comment being prefaced by a number in square brackets in both the text and the commentary.

${ }^{28}$ The text is edited in Manșūr b. Ba'ra al-Dhahabī al-Kāmilī, Kitāa kashf al-asrār al- ilmiyya bi-dār al-d̦arb al-mișriyya, ed. 'Abd al-Raḥmān Fahmī, Lajnat ihyā' al-turāth al-islāmī, Majlis al-a "lā li-shu”ūn al-islāmī 8 (Cairo: Mu'assasat dār al-tahrīir, I966). An English translation is available in Martin Levey, Chemical Aspects of Medieval Arabic Minting in a Treatise by Manșūr Ibn Ba'ra (Tokyo: History of Science Society of Japan, I97I), and extracts have been translated into English in Andrew S. Ehrenkreutz, "Extracts from the Technical Manual on the Ayyūbid Mint in Cairo," Bulletin of the School of Oriental and African Studies I 5 (1953): 423-47.

29 Manșūr b. Ba'ra al-Dhahabī al-Kāmilī, Kashf al-asrār, 73-4. For this article, we have left out two other passages of the treatise describing cupellation: chap. I2 (on 78-82) and chap. I4 (87).

30 Walter Hinz, Islamische Masse und Gewichte, umgerechnet ins metrische System (Leiden: Brill, I970), 29.

${ }^{1}$ Riche and Gélis, L'art de l'essayeur, I 56.

32 Levey, Chemical Aspects, 69.

33 The same observation was made by Guillaume Sedacer (fourteenth century) in his Sedacina, and the modern translator of that text was also puzzled and unable to translate the text properly; Sedacer, La Sedacina ou l'Euvre au crible, vol. 2, 133 . 


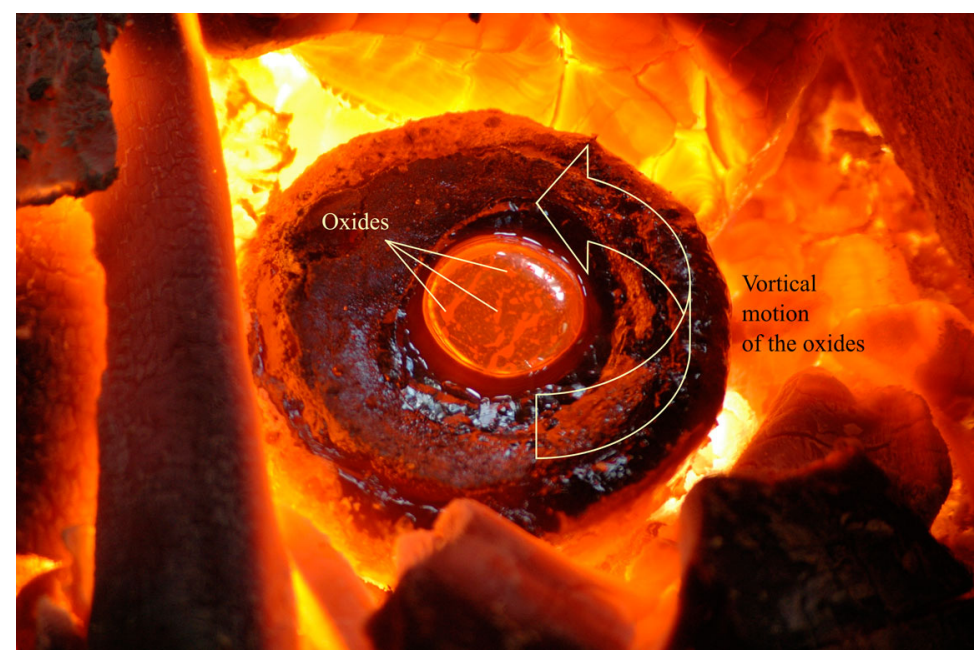

FIGURE 6 Cupellation. The oxides appear as lighter spots, which rotate on the surface of the molten silver. (C) Nicolas Thomas.

\section{Maslama b. Qāsim al-Qurțub̄i, Rutbat al-ḥakīm (339-342/950-953)34}

The Rutbat al-ḩakim (The Rank of the Sage) is an alchemical treatise written in 339342/950-953 by Maslama b. Qāsim al-Qurțubī (293-353/905 or 906-964). It is one of the earliest, if not the first, alchemical treatise written in al-Andalus (Iberian Peninsula). Maslama was a muhaddith (a specialist in Islamic traditions) interested in the so-called occult sciences: he is also the author of the famous Ghāyat al-hakìm, better known under the title of its Latin translation, Picatrix. The Rutbat al-hakim contains technical descriptions, including that of cupellation, which is explained at the end of the fourth maqāla of the Rutba.

The description of cupellation in the Rutbat al-hakim is as follows: ${ }^{35}$

34 Godefroid de Callataÿ and Sébastien Moureau are currently preparing a critical edition of the Rutbat al-ḥakim. No edition or translation of the treatise has been made so far. On Maslama and the Rutbat al-hakim, see Maribel Fierro, La heterodoxia en al-Andalus durante el periodo Omeya (Madrid: Instituto Hispano-Arabe de Cultura, I987), I 2930, "Bāținism in Al-Andalus. Maslama B. Qāsim Al-Qurțubī (d. 353/964), author of the Rutbat Al-Hakim and the Ghāyat Al-Hakim (Picatrix)," Studia Islamica 84 (I996): 87-I I 2, and "Plants, Mary the Copt, Abraham, Donkeys and Knowledge: Again on Bāținism During the Umayyad Caliphate in Al-Andalus," in Differenz und Dynamik im Islam. Festschrift für Heinz Halm zum 70. Geburtstag, ed. Hinrich Biesterfeldt and Verena Klemm (Würzburg: Ergon Verlag, 20I2), I25-44; Godefroid de Callataÿ, "Magia en al-Andalus: Rasā’il Ijwān al-Ṣafā', Rutbat al-Hakīm y Gāyat al-Hakìm (Picatrix)," Al-Qanțara 34 (2013): 297-343, Mourad Kacimi, "Nuevos datos sobre la autoría de la Rutbat al-ḥakìm y la Gäyat al-ḥakìm (o Picatrix)," eHumanista/IVITRA 4 (2013): 237-56, and "La relación de Maslama al-Maŷrịṭī con las obras Rasā’il Ijwān al-Ṣafā', Risālat al-ŷāmi`a, Rutbat al-ḥakīm y Gāyat al-ḥakīm," Anaquel de Estudios Árabes 25 (20I4): 29-44; Godefroid de Callataÿ and Sébastien Moureau, "Towards the Critical Edition of the Rutbat al-ḥakim: A Few Preliminary Observations," Arabica: Revue d'études arabes et islamiques 62 (20I 5): 38 5-94; "Again on Maslama Ibn Qāsim al-Qurțubī, the Ikhwān al-Ṣafā'... and Ibn Khaldūn: New Evidence from Two Manuscripts of the Rutbat al-hakimm," Al-Qanțara 37 (forthcoming 2016); and "A Milestone in the History of Andalusī Bātinism: Maslama b. Qāsim al-Qurțubī’s Riḥla in the East,” in Histories of Books in the Islamicate World, ed. Maribel Fierro, Sabine Schmidtke, and Sarah Stroumsa (Leiden: Brill, forthcoming).

35 The translation is based on the text of ms. Istanbul, Süleymaniye Kütüphanesi, Beşir Ağa 505 , fol. $57 \mathrm{r}$-v, and Istanbul, Süleymaniye Kütüphanesi, MS Ragıp Paşa 965, fol. I28v. 
[1] As for the case in which (gold or silver) is mixed with of one of the two leads [ahad al-rașāssayn], it can only be washed by removing the lead from it. Understand. This is the good washing, this is (the washing) which separates the dirty body from the pure body. This is like the silver mixed with lead, it is separated from it by this (process): [2] one makes for it a cupel $[r a w b \bar{a} s]$ of bones, which is what is called the "head of the dog" [ra's al-kalb] and of which the common name is k $\bar{u} j a-$ which is the crucible [bütaqa]-and this must be made of burnt bones. One melts the silver in it, one gives it a strong fire: the cupel will absorb and receive the lead, the fire will make its subtle (part) fly away and extirpate it ${ }^{36}$ and there will remain unmixed [khāliș] silver with no adulteration [ghishsh] in it. [3] Similarly, the washing of (silver) from copper is done by putting it into this instrument [āla] and feeding it continuously with lead so that it comes out clean and unmixed. This is one type of work.

As for the washing of gold from silver and copper, there are two types (of washings). Its washing from copper alone is like the washing of silver from copper by the means of lead and the "head of the dog" as (explained) above, [4] and if you want to feed them both with sulphur, it will burn the copper and the gold will remain unmixed. As for the washing of gold from lead, it is exactly similar to the washing of silver from lead.
[1] Lead and tin are both called rasās in Arabic, although other names exist to distinguish them. ${ }^{37}$

[2] The word rawbās obviously indicates the cupel in this passage instead of the bellows, maybe because of a confusion of the author, or because of a problem in the manuscript tradition. The expression $r a$ 's al-kalb, "head of the dog," is not common, and we have not found any mention of it elsewhere..$^{8}$ The word $k \bar{u} j a$ or $k \bar{u} j$ is found along with $k \bar{u} k h$ and $k \bar{u} h$ (in Hamdānī) to designate the cupel: these words only differ by the point of the last letter (كوح, كوخ, كوج).

[3] The lead must be added piece after piece. If one adds all the lead at once at the beginning of the process, it immediately turns into litharge and is absorbed by the cupel, and does not have time to dissolve the copper oxide. This detail is important and is not explained in the other texts.

[4] Maslama refers here to the purification of gold (and not silver) by cementation, another process in which gold is mixed with a cement containing sulphur which will create sulphides with the other metals.

\section{Hamdānī, Kitāb al-jawharatayn al-'atīqatayn (first half of the fourth/tenth century) ${ }^{39}$}

\section{The Kitāb al-jawharatayn al-'atīqatayn min al-șafrā' wa-al-bayd̄̄' (Book on the Two Noble Substances from the Yellow and the White) is a treatise written in the}

36 We propose reading wa-taqla'u-hu (وتقلعه ); MS Beşir Ağa 505 reads ونعلفه and MS Ragıp Paşa 965.

37 See Fabian Käs, Die Mineralien in der arabischen Pharmakognosie. Eine Konkordanz zur mineralischen Materia medica der klassischen arabischen Heilmittelkunde nebst überlieferungsgeschichtlichen Studien, Akademie der Wissenschaften und der Literatur. Veröffentlichungen der orientalischen Kommission 54 (Wiesbaden: Harrassowitz, 20I0), $582-6$.

$3^{8}$ One could conjecture a phonetic distortion : $r a$ 's al-kalb could come from the expression $a l$-ra's al-qalb, the reversed head, which could correspond to the description of the bellows used for cupellation (the rawbās, described as $m a k b \bar{u} b$ al-ra's by Ibn Ba'ra, see above in "Experimentatio ancilla philologiae" section).

39 The text is edited in al-Hasan ibn Ahmad Hamdānī, Al-Jawharatayn al-'atīqatān. Die beiden Edelmetalle Gold und Silber, ed. and trans. Christopher Toll (Uppsala: Almqvist \& Wiksell, I968); Hamdān̄̄, Kitāb al-jawharatayn al-'atīqatayn al-mā'i'atayn min al-șafrā' wa-al-baydạ̄', ed. Yūsuf Muhammad 'Abd Allāh (Șan'ā': Maktabat al-irshād, 2003); Hamdānī, Kitāb al-jawharatayn al-'atīqatayn al-mā'i'atayn min al-ṣafrā' wa-al-bayḍā', ed. Aḥmad Fu'ād Bāshā (Al-Qāhira [Cairo]: Dār al-kutub wa-al-wathā'iq al-qawmiyya, 2009). The text was translated into German in Hamdānī, Al-Jawharatayn al-'atiqatān; extracts were translated into English in Douglas Morton Dunlop, "Sources of Gold and Silver in Islam According to Al-Hamdān̄̄ (Ioth Century A. D.)," Studia Islamica 8 (I957): 29-49, and into French in Ben Romdhane, "Contribution à l'histoire monétaire du Maghreb médiéval," and Audrey Peli, "Monnaies, métal et pouvoir : frappes et techniques monétaires au Yémen ( $\mathrm{II}^{\mathrm{e}}-\mathrm{VI} \mathrm{I}^{\mathrm{e}} / \mathrm{VIII}{ }^{\mathrm{e}}-\mathrm{XII}{ }^{\mathrm{e}}$ siècles)" (Ph.D. dissertation, Université de Paris I - Panthéon-Sorbonne, 2008). On Hamdān̄̄ and this treatise, see Dunlop, "Sources of Gold and Silver in Islam"; Oscar Löfgren, "al-Hamdān̄̄," EI $I^{2}$, I97I; Christopher Toll, "Al-Hamdān̄̄ as a Scholar," Arabica: Revue d'études arabes et islamiques 3 I (I984): 306-I7; Ben Romdhane, "Contribution à l'histoire monétaire"; and Audrey Peli, "Les techniques minières et métallurgiques dans la péninsule arabique du VII ${ }^{\mathrm{e}}$ au XII ${ }^{\mathrm{e}}$ siècle” (Masters thesis [DEA], Université de Paris I Panthéon-Sorbonne, 2003-2004), "Monnaies, métal et pouvoir," and "Les procédés de la production monétaire dans le Yémen médiéval," Chroniques du manuscrit au Yémen I4 (2012). 
first half of the fourth/tenth century by Abū Muhammad al-Hasan ibn Ahmad al-Hamdān̄̄, polymath, poet, geographer, and genealogist, who was born in San' ‘̄à' (Yemen). It is a text on gold and silver, in which Hamdānī explains where and how these precious metals were extracted, refined, and used (for coins and jewellery) in the Arabian Peninsula. This treatise is one of the most thorough texts on the topic, containing incredibly precise descriptions of techniques and processes. However, being a highly technical treatise written by an author who was a scholar rather than a technician, its language is complicated and hard to understand. The author deals with cupellation in chapters twenty-one and twenty-two, focusing on the extraction of silver (istikhrāj al-fidda min al-ma'din) and its refining (ikhlās al-fiḍ̂ wa-mu'ānāt fì hādha al-wajh).

Hamdānī gives one of the most precise accounts of cupellation, yet many passages remain obscure. The text explains: ${ }^{40}$

[1] Then, one proceeds with ashes of ' $u r \bar{a} b^{4 \mathrm{I}}$ or ashes of juniper ['ar'ar], one sieves them and softens them with water. [2] One makes for (the ingot) bellows of purification [kir al-ikblass], one puts in it the ashes and a dish [jafna] in which one has inlaid pebbles $[f i b r]$ well covered with stones until it becomes dry.

Then, one puts the lead in the middle of this dish, one mounts bellows [minfäkh] with a rawbās on it, similar to the purification bellows, throws juniper charcoal [sawd al-'ar'ar] on the lead, kindles (the charcoal) and continually throws charcoal while the lead is burning and becoming litharge [martak], [3] until, when all the lead is burnt and the silver remains in the middle of the litharge, one soaks a rag and throws it upon (the silver) so that the coldness enters (the silver). Then, one pours water upon it, takes off the litharge as it is, and extracts the silver from the middle of the (litharge).

This is for the substance itself (consisting) of silver containing (only) a bit of lead; as for the (substance consisting) of much lead and less silver, or less silver and a lot of lead residues (or weight $)^{42}$, the (silver) button [nuqra $]^{43}$ which comes out of the middle of the litharge must necessarily be put back to the purification bellows [kir al-ikbläs], and from this comes out the "burnt plant" (or the burnt nugget?) [al-nabāt al-haraq], and the first (silver) button [nuqra] (i.e. the one obtained from silver with a bit of lead only) is better. (...)

The substance [jawhar] of silver is the stones [hijāara] of silver (i.e. silver ore). [4] From some of them, one extracts from one pound [raț] (of ore) half a pound of silver, this is the precious
[1] The cupel is here made of the ashes of vegetable matter rather than bones (which is much more usual in texts, and considered better by the authors); making cupels with vegetable matter is easier than with bones. Experimentation allows us to confirm that this use of vegetable ashes works; the fact that the silica contained in the ashes can interact with the lead oxide is not a problem thanks to the low concentration of silica (the choice of the plants is important for this reason). The sieving is very important, since the ashes must be fine and as pure as possible for a good cupel.

[2] This passage is obscure. One could read $k \bar{u} r$ instead of kivr, meaning "forge" instead of "bellows." The ashes are put inside the dish. The fact that the cupel must be dried is important in order to avoid cracks in the cupel when it is heated. The reason for inlaying pebbles may be to avoid cracks when the cupel dries (as grog), since the tensions are higher when the amount of ashes is larger. [3] Hamdānī here explains how to refine argentiferous lead: since the silver concentration is very low, the cupel cannot absorb all the litharge. The result consists of two distinct liquids: a mass of molten silver in a bath of litharge. One cools it quite quickly to solidify both the litharge and the silver, and obtains something like a fried egg. The litharge is then broken off to leave the silver button. Hamdānī does not specify here an important detail which appears when experimenting: the charcoal must obviously be taken off before throwing the water on the silver.

[4] There is a problem with this passage. Silver is usually extracted from galena (lead sulphide, $\mathrm{PbS}$ ), which often contains a small amount of silver. The

\footnotetext{
$4 \circ$ Hamdānī, Al-Jawharatayn al-'atīqatān, 27I-89, and Kitāb al-jawharatayn (2009), I 5 I-5

$4^{\mathrm{I}}$ Toll and Bāshā both read 'urāb, but Toll does not translate the word.

42 The Arabic text can be read kathīr al-thufl or kathīr al-thiql.

43 Here and below, the word nuqra designates not only the ingot, its usual technical meaning, but also the silver button (or bath, when melted) during the cupellation. The word is translated variously as "button," "bath," or "ingot" in this article, for the sake of clarity.
} 
and abundant (silver ore). After this one (comes the ores which contain for one pound) a third pound (of silver), a fourth, a fifth, a sixth, an ounce $[\bar{u}$ qiyya $],{ }^{44}$ up to the full weight dirham [dirham qafla] and what is between those depending on the good or bad (quality of the ore). usual ratio is, in the best cases, around one to three per cent, as in the mine of Radrād (now Jabalī, with a concentration of one per cent), described as one of the best by Hamdānī. ${ }^{45}$ Experimentation proves that one cannot refine lead containing only one to three per cent of silver only by means of an absorbing cupel: there must be a part of the process that Hamdāni omits or that he is unaware of. One possible solution is that bullion lead (i.e. argentiferous lead obtained from ore) is continuously added in the cupel during the process, and that the silver concentration of the metal increases step by step, but if so there must have been another way of clearing off the litharge, since the cupel could not absorb the entire amount of litharge; the fact that Hamdāni mentions above that the silver is enveloped with litharge at the end of the process indicates a large amount of lead in the alloy.

\section{Chapter on the refining of silver and its works [mu'ānāt]}

[5] There are three kinds of refinings: the first one is the mineral one (i.e. the refining of the ore), which is the one that we have mentioned; the refining of what is called the white silver, which is (the silver) which lacks one tenth (from being pure) or less; and (the refining of the silver) which lacks more than (one tenth), which is dust-coloured, vile and black, up to (the silver) which gives one fifth (of pure silver) and one sixth, and one tenth.

[6] As for the refining of (the silver) which is called white, it is easy, especially the one which lacks half of one tenth (i.e. I/20) or two fifths (of one tenth, i.e. I/25), because it is like a melting and it is called purification [isfa $\left.\bar{a}^{\prime}\right]$. [7] It does not need more than (one) unveiling [kashafa], especially when the ingot [nuqra] is fine. [8] If it (gives) good silver [fa-in kāna min$h \bar{a}$ fidd $\mathbf{d} a$ saliha], it needs more than this. If (the silver) is vile, it needs unveilings [kashafāt] until the bones absorb (the lead) and end the absorption, so that their absorption becomes small, and that (the silver) comes out and remains $[t a b q \bar{a}]$. [9] And then one presses ${ }^{46}$ a second cupel [ku $\left.k b\right]$ for it and puts it back (into the fire); this return is called the "reversal" [al-qalb], because the (upper) side of the (silver) button [nuqra] is put facing downwards.
[5] The passage is not clear. Hamdānī seems to define three kinds of cupellation depending on the quality of the starting materials: ore, almost pure silver, and impure silver.

[6] The silver which lacks one twentieth is probably a silver which contains one twentieth of impurities, which is very easy to refine.

[7] The kashafa is a very concrete way of describing the process of cupellation. Experimentation allows one to understand this term literally: the litharge at first forms a veil on the surface of the silver, and this veil disappears when the last traces of litharge flow to the edges of the molten silver (Figures 7 and 8 ). Therefore, the word kashafa seems here to refer to a process of cupellation: the less pure the silver, the more cupellation processes it needs.

[8] There is a problem with this sentence: the silver needs more than one iteration of the process if the silver is not good. The text may be corrupted here. [9] When the ingot contains many impurities, it needs more than one cupellation in order to be refined. The silver button is turned upside down since impurities could have been trapped under the button.

\footnotetext{
44 The usual pound contains twelve ounces.

45 Paul Benoit, Jean Féraud, Françoise Micheau, and Florian Téreygeol, "Nouvelles recherches sur la mine d'al-Jabalî," Chroniques yéménites I I (2003): 47-66, Audrey Peli and Florian Téreygeol, "Al-Raḍrāḍ (al-Jabalī): a Yemeni Silver Mine, First Results of the French Mission (2006)," Proceedings of the Seminar for Arabian Studies 37 (2007): I87200.

${ }^{46}$ Literally "one hits," “one strikes” (daraba), meaning the impression of the cupel.
} 


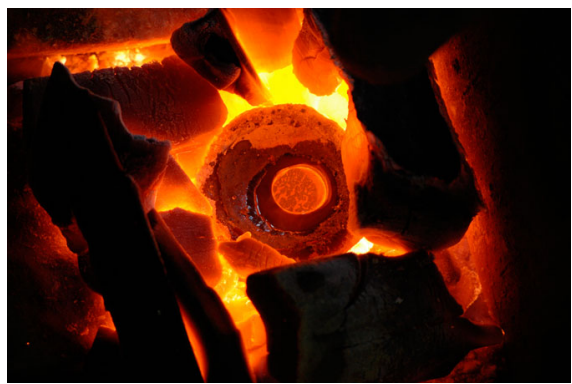

FIGURE 7 Molten silver with a "veil" of oxides during the cupellation process. (C) Nicolas Thomas.

Refining is an important operation that many people perform. It pertains to the category of widespread arts in which the expert [khässs] and the common ['ámm] are equivalent or almost equivalent. There are a lot of descriptions of (this process), except that we warn (people) about a thing that the one who seeks to know it needs. The first (thing to know) is that the best (material) to purify (silver) is crushed burnt bones, and the best (bone) and the one which absorbs the bad mixed (metals) in silver the most is a bone without marrow [mushāsh] from cows or camels, and the absorption of a bone with marrow $[q a s a b]$ is small. The Yemenites refine (silver and gold) with bones, [10] and others use salt and crushed bricks. [11] The best charcoal for purifying is the charcoal of acacia [qaraz] ${ }^{47}$ then of the Arabian balsam tree [bashäm] and the $t a l a b .^{48}$ In Syria, one uses oak charcoal [ballūt]. One also refines (silver and gold) with wood: wood eats faster what is in silver, because it shows what is in it.

[12] When one refines with charcoal, and cleans and purifies the place of the pincers with a stick, it shows all the impurities that remain in the (silver). [13] The hollower the cupel, the more silver it (may contain), the less hollow, the more the fire acts on the surface of the (silver) puddle [nuqra]. [14] When the weight of the bones is high thanks to the water (they contain), especially the bones with marrow [qasab], it makes the cupel harder and reduces its absorption, and the silver is too abundant for what decreases from the surface of (the cupel). When the weight (of the bones) is low, the blow (of the bellows) blows it away and,$-{ }^{49}$ (the cupel) cracks and the silver

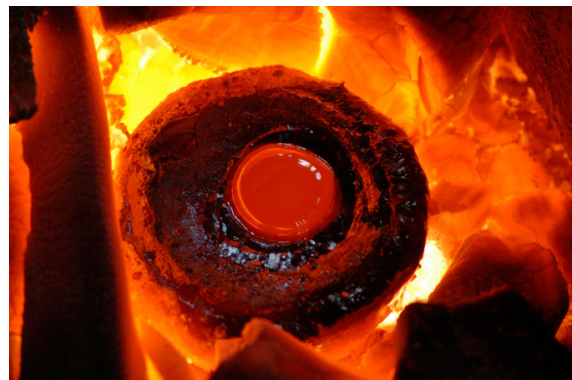

FIGURE 8 The silver without the "veil" of oxides, at the end of the cupellation process. (c) Nicolas Thomas.

[10] The latter process on gold refers to cementation, and not cupellation.

[11] It is hard to explain this passage precisely. There are indeed differences between charcoal and wood, and also between different woods: woods such as birch will produce a hot flame for a short period of time, and woods such as oak will burn slowly and gently. However, Hamdānī's emphasis on the differences between all these woods is perhaps more due to tradition than to practical experience: in many cases, technical traditions are common among craftsmen, who scarcely change a technique which works. [12] The passage maybe refers to a test which one can read in Theophilus's Schedula in which one uses a stick to check if some impurities remain in the silver. ${ }^{5 \circ}$ [13] Hamdānī points out the importance of the surface-volume ratio: this ratio must be high, i.e. the cupel must not be too hollow, so that the fire can "act" (i.e. oxidise the other metals).

[14] This entire passage shows the importance of the method used to make the cupel, which is one of the key elements in cupellation. The description is very

47 Either acacia wood, or another part of the tree, often the fruit; the meaning of the word is not precisely identified. See Edward William Lane, An Arabic-English Lexicon (London: Williams and Norgate, I863), s.v., and Max Meyerhof, ed. and trans., Sharh asmā' al-'uqqār (L'explication des noms de drogues). Un glossaire de matière médicale composé par Mä̈monide (Cairo: Imprimerie de l'Institut Français d'archéologie orientale, I940), I35. The expression biläd al-qaraz, country of the qaraz, is a surname of Yemen, Hamdānīs country.

$4^{8}$ The $t a^{\prime} l a b$ is not identified. It is described as a tree from which one makes bows in the Lisān al-'arab, s.v.

49 The Arabic text is unclear here. Toll reads ولايثناءه and Bāshā reads ولاُه , but both are very problematic.

$5 \circ$ Dodwell, Theophilus, 75 . 
flows in the ashes below (the cupel). The (cupel) with a moderate weight has a good absorption and purifies what is white in the back [al-qafā $]$ of the (silver) button [nuqra]; otherwise, if it contains a lot of moisture from the water, the whiteness of the back (of the button) becomes cloudy. When the calcination of the bones is not entirely done and the (resulting) powder is black, especially for bones with marrow, the absorption is low and the back of the (silver) button [nuqra] becomes cloudy, particularly when the weight of (the bones) is high. When the ashes under the cupel are dense [kathufa], it cooks better [andaja] the bottom of the (silver) button [nuqra] and hastens its refining, and if there are (only) a few (ashes), it is the contrary ['alā 'așr ${ }^{51}{ }^{1}$

The conditions (to obtain this) is to add lead according to a certain amount [qadr]. [15] If one puts in more (lead) than the (needed) amount, it does not burn (completely) until (or so that) some of the silver goes away after the quantity (of lead has gone away $)^{52}[$ ba da al-miqdār $] 5^{53}$ and if there is not enough (lead), the silver thirsts [ta'attashat] and the fire quickly (attacks) it because there is no lead in it to preserve it and upon which the effect of the fire acts.

[16] One of the signs that the moist (silver) button [nuqra] that one has obtained [wa-min 'alämat alnuqra al-rațba allati $y u d r i k u-h \bar{a}$ ] no longer contains lead is that its surface wrinkles and erupts and that things like barley grains appear on it when they are put into fire. [17] If (the silver) solidifies while almost but not completely (refined) and there is no lead at all, its surface wrinkles in the (form) of the balm-tree [balasān] . A difference between obtaining (purity) in refining white (silver) and in refining black (silver) is (to be observed) when the lead residues appear dismembered and scattered, such as gecko or viper eyes or smaller: how small they are is the indication of the (purity) of the silver that one has obtained. [18] If it is the refining of white silver, these eyes wear off and a film, glittering and silky as the feather of a peacock's tail, appears on the surface of the (silver) puddle [nuqra]. Then, one removes this film with a stick and breaks it [qata'a], it solidifies and when one extracts it, its surface comes out as if it was the surface of an iron mirror. If it is the refining of black silver, these eyes do not wear off but coalesce on the side (of the silver) in proportion to the amount (that the silver) contains, and it becomes as if it were something (made) of subtle oil which solidifies a little. When one stops to blow (on it), what has not solidified glitters. [19] The solidification begins in the hard to understand, since the information here pertains more to the perception of the senses (touch and sight) than to a rational explanation. Hamdānī seems to describe the importance of the fineness of the bone powder, which must be neither too fine nor too thick, and the importance of wetting the bones only a little when making the cupel (experimentation proves that one needs only a very small amount of water to make the cupel).

[15] The proportion of lead is very important and must correspond to the need. The action of the fire on lead is its oxidation. A large amount of lead preserves the silver from vaporisation, since lead decreases the melting point. The litharge also decreases the melting point of the copper oxide produced.

[16] This description echoes the description one finds in the Dialogus de Scaccario (twelfth century). ${ }^{54}$ It maybe refers to the sprouting or spitting of the silver: when almost completely pure silver is melted, it absorbs a lot of oxygen, and if one then cools it quickly, the oxygen exits the silver, producing pustules on the surface of the metal. The expression "moist button" likely signifies the button which has been cooled with water.

[17] The silver in question is silver containing impurities other than lead. The purer the silver, the more it shines.

[18] This passage is a very detailed and subtle description of the silver after cupellation. The film is likely an oxide layer on the surface of the silver (Figure 9). Hamdānī is probably describing cupellation that was stopped before the end of the process: the film is either litharge which has not been removed, or traces of other impurities which did not dissolve because there was not enough lead.

[19] The metal will solidify first, and the litharge around the metal afterwards, so the solidification begins in the centre.

\footnotetext{
${ }^{1}$ The phrase is not common, and the meaning remains uncertain; Bāshā is puzzled by the word and suggests reading 'aks in his apparatus.

52 Or, "after the measurement" (in an assay?).

53 Toll proposes reading qidr instead of $q a d r$ (proposed by Bāshā), which completely changes the meaning of the sentence: "The condition (to obtain this) is to put lead into a pot [qidr]. If one puts more (lead) than (what) the pot (can contain), it does not burn (completely) until some of the silver goes away after the quantity (of lead has gone away)."

54 Johnson, Dialogus de Scaccario, 40.
} 
centre and the edges seem to rotate. If one spatters it with water, this glitter stops and it will produce a (silver) button [nuqra] with a brownish surface and these eyes do not wear off from it.

The sign of the button [nuqra] of black (silver), besides the character of its surface, is the entire absorption of its back [qafan] and its colour like henna. [20] The sign of the button [nuqra] of white (silver) is that its absorption is in the edges of the back and that the centre of the back is white: the size of the white area is in proportion to the quality of the silver, and its weakness is from the limit of what one calls white. The one that has a lot of whiteness and little absorption is the best. When you see a (silver) button [nuqra] with a pure surface, smooth, with a white back, and with (traces of) burn or wiping (or soaking) [mashsh], it is a button [nuqra] of white silver (purified) a second time $\left[m u^{\prime} \bar{a} d a\right]$. This concerns the (silver) button [nuqra] (refined with) bones.

[21] As for (the silver) refined with salt and bricks, its back entirely absorbs [yasta'immu minbu al-qafa bi-al-sharb] because the salt bubbles and melts, and the back of the (silver) button [nuqra] receives it, while the bones do not bubble and melt.

[22] One of the signs of (the fineness) of the silver and of the small (amount) of lead is that the pincers stick to it when one grabs it with them. If it (the silver?) is moistened (or watered or melted?) [kāna riyyan] and is more (refined) than this one, (the pincers) do not stick. [23] When there is a lot of silver in the cupel and some is removed, or when there is (only) a little amount [wazn] (of silver in the cupel), (this) damages its border $[h \bar{a} f a]$ under the pressure of the rawbās so that there is blackness between (the border) and (the rawbās) and that the fire acts (on the silver), otherwise it does not melt; and when (the silver) melts, it reduces [khafada] it (?). [24] If the silver is black, the best thing for it and the fastest way to collect it $\left[l i-j a m^{\prime} i-h \bar{a}\right]$ is to give it some lead before it melts, which will be for its melting, for its collecting [li-yajma'a-hā], as the tinkār in a greasing [ $\bar{\imath} d \bar{a} k]$. If this causes dirt, burn it. During the melting, a film will appear on the (silver): wet this film a little with lead in order to dissolve the particles of silver it contains, [25] then remove it with pincers after it rotates on the surface of the (silver) button [nuqra], and the button will take what is of its own kind in the film, of its genus (i.e. the silver). [26] Too weak a current (of air) will cool (the silver), too strong burns it, the most favourable is a

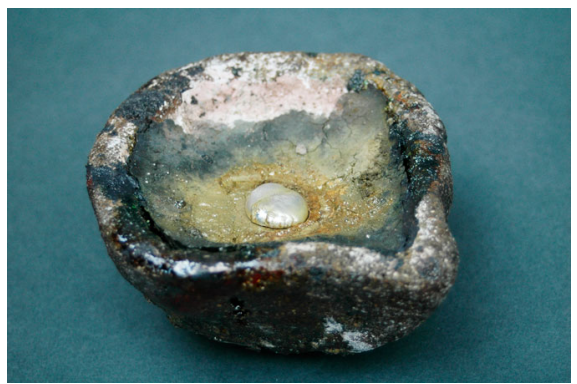

FIGURE 9 Silver button, still covered with litharge and oxides after a cupellation. (c) Nicolas Thomas.

[20] The white silver is pure silver, the black silver is impure silver (less than twenty-five per cent of silver). [21] The silver refined by the second process, i.e. the cementation, is indeed less pure than the one refined by cupellation, since the silver is refined in its solid state in the cementation. The "back" of the button is its bottom side.

[22] Pure silver, when melted, does not stick to the pincers, while it does when there are impurities (actually, the impurities stick to the pincers, but a small amount of silver comes with them).

[23] The passage is hard to understand literally. Hamdānī seems to describe the orientation of the bellows and the need for the air current to touch the entire surface of the silver: if there is too much silver, the surface is too large and the air does not touch the silver everywhere. In addition to this, the air coming from the bellows must also blow on the charcoal.

[24] The lead lowers the melting point of the silver; lead acts as a flux. The word tinkār usually refers to the chrysocolla, or sometimes to a kind of borax. ${ }^{55}$ Borax and chrysocolla can be used as fluxes.

[25] On this rotation, see p. 20 above.

[26] This section is a good example of the description of a gesture: this act cannot be learned by reading a text, but is part of the "know-how" (or tacit knowledge) more than algorithmic knowledge of the process. Experimentation allows one to feel how 
moderate current, which makes the release (of the silver from lead) easier [kāna ilā al-tahrīr aqrab].

When you have refined the black silver once, its cupel will be somewhat more soaked [arwā] (with litharge) than the cupel of the "reversal" 56 [ $[k \bar{u} k h$ al-qalb] because of the slags and the lead which are collected [yujma] in it. It is better [awfar] to take off the (silver) button [nuqra] with a stick than with the pincers, since one can fail to do it with the pincers or notch the cupel.

[27] The best refining bellows are those with two flaps [minfākh al-șarafayn], (the bellows with only) one skin are useless. When one uses the (bellows with) two skins, it is the same as the bellows with two flaps. The button [nuqra] of black (silver) is refined in one cupel, but it is better [awfar] to (submit it to) the "reversal" [alqalb $]^{57}$ in another (cupel), because (this new cupel) absorbs what remains in (this button). The first cupel could blot a little [yakādu an yarwā] but does not receive what remains of its slag [akkhir khabathi-hā] (i.e. what remains of litharge with impurities): the fire burns it along with a little of silver.

[28] The best thing for the (silver) button [nuqra] when covering [taghziya] it is to have charcoal between it and the rawbās, otherwise (the current of air) erodes it [sahala]. [29] When you uncover the (silver) puddle [nuqra] (i.e. remove the charcoal) and see glittering veils on it that appear from its middle to its edges, this is yellow copper (or brass) [șfr], and if they tend to be a sheet [waraq], it is lead-this is when there is a lot of it. When a side [jānib] (of the refined button) $\operatorname{cools}^{58}$ in the furnace $[k \bar{i} r]$, the bones do not absorb (the impurities) in it and the (silver) button [nuqra] will not be free from its moisture on this side. [30] As for the edges (or brinks, or furrows, or hollows) [ spattering of the water, and they are more abundant in the refining of white (silver) and of dusty (silver). When the absorption is on the entire back of the (silver) button [nuqra], the place of the edges $[$ burū $f]$ (has the form) of a rosebud [nujūm wardiyya], and the edge [harf] may be in it if one has quickly spattered (the water).

[31] The most skilful refiners are the Egyptian ones or the refiners who follow their refining method, because their (silver) button [nuqra] is smooth [mustawiya] in the middle and the edges, albeit the edges of their (silver) buttons [nuqra] complex it is to use the bellows properly: finding the appropriate blow requires a lot of experience, and cannot be done easily at first.

[27] Hamdānī refers here to the double-acting bellows, which experiment has shown to be much more efficient than simple bellows. It produces a continuous current of air.

[28] Hamdānī describes how to put charcoal on the cupel and how the air of the bellows must impinge upon the silver to refine it. The metal must be covered so that the blowing does not damage it (especially when it is melted, the air current could splash some metal out of the cupel).

[29] Hamdānī seems here to try to describe the process as precisely as possible. Sufr usually means yellow copper or brass, ${ }^{59}$ but probably refers here to the colour of the litharge in a certain moment of the cupellation. It is hard to confirm what he says, since it is hard to perceive exactly the colours that he describes and the perception of colours is quite subjective, especially in such different epochs.

[30] The passage is very obscure and the meaning of the word harf (pl. hurüf) is not clear in this context. It could refer to the edges of the metal puddle, or to the small hollow one usually presses in the centre of the cupel for the silver button, or even small cracks which sometimes appear in the ashes due to the litharge. The water in question could also be the litharge in its liquid state.

[31] The borders of their button are thin, which means that the puddle of molten metal is shallow (and that the surface-volume ratio is high).

[32] The passage is too concise to be understood clearly.

\footnotetext{
${ }^{56}$ The cupel for the second refining of an ingot, see above.

57 See n. 55 .

${ }_{58}$ Toll reads yaruddu, but Bāshā's reading barada makes more sense (the words differ by only one diacritical point).

59 See Dietlinde Goltz, Studien zur Geschichte der Mineralnamen in Pharmazie, Chemie und Medizin von den Anfängen bis Paracelsus (Wiesbaden: Franz Steiner Verlag, I972), 265-6; and Käs, Die Mineralien, 757-9.
} 
are thin. [32] They are the most skilled persons for refining a big (silver) ingot [nuqra] which adds two hundred to the thousand (twenty per cent) [nuqra kabìra mimmā yazìdu 'alā al-alf al-mi'atayn].

[33] Gold is refined when one puts some rașās alqal $^{\leftarrow}$ in it. [34] One does not put lead on silver in the cupel before (the silver) is melted unless it begins to spatter. $^{60}$ When the lead has gone in the cupel and one does not believe that it has gone to its place [yahillu bi-mawdi'i-hi] when the silver is melted, it goes after that into the ashes [yutba'u dhālika al-ḥalal ilā al-ramād].

The description and the conditions of the refinement (of silver) are numerous. ${ }^{6 \mathrm{I}}$
[33] The expression rașās al-qal'乞 is not clearly identified here. Usually, the term designates tin (also called qașdir), but it does not seem the case here; rașās alqal $\bar{\imath}$ can also refer to cassiterite or to lead compounds such as galena. ${ }^{62}$

[34] Experimentation proves that it is better to add the lead when the silver is already melted, otherwise the lead oxidises before being alloyed with the metal one wants to refine. Here, the author perhaps advises putting in the lead before the silver is molten when there is an impure silver which spatters, in order to prevent the silver from spattering.

\section{Conclusion}

Experimentation is a powerful tool, among others, for the study of history, especially in the field of history of science. Indeed, experimentation reveals much valuable information to the researcher, although it must be evaluated with care. The aim of using historical experimentation is not to produce new science but to better understand historical documents and to better grasp how science was practised and developed. In addition to a better understanding of textual descriptions, experimentation often gives us a better understanding of the process itself, which in turn provides new elements for understanding history.

In our study of cupellation, our knowledge acquired from carrying out similar practices helped us decipher many obscure instructions. For instance, the "unveiling" (kashafa) that the silver requires would not have been easily explained without seeing the litharge "veil" appear on the surface of the molten silver. Although this meaning might have been guessed at, in other cases, experimentation allowed us to understand what we could not have otherwise comprehended. Indeed, it is very unlikely that we would have correctly guessed the meaning of the "rotation of the silver" in Ibn Ba'ra's description without having seen it ourselves, especially since there was a very plausible and convincing philological way of bypassing the problem (by reading idh aradta instead of $i d h \bar{a}$ dārat).

Experimentation is also one of the few ways to acquire information on technical know-how. Any technique contains two kinds of knowledge: knowledge that we might call "algorithmic," which can be explained by words (for instance in recipes), and the "know-how," the knowledge of the body, the tacit knowledge. For instance,

\footnotetext{
60 The meaning is uncertain and the reading is hypothetical: Toll and Bāshā both read ترتشن , but Toll quotes the reading ترس (also from two manucsripts); we use the reading ترن ترن in two manuscripts, and Bāshā quotes (putting the dots on the varied reading given by Toll), but a more definitive statement would require examination of the manuscripts.

6I The chapter ends with the enigmatic sentence: "The best thing to eat with it [yu'kalu 'alay-hi] is the grill, and the best thing to drink with it is the cooked or macerated wine."

62 See Käs, Die Mineralien, 90I-3.
} 
one can be a textual specialist of the violin, by knowing where to place one's fingers to create each note, and how to hold the bow, and how to describe any movement needed to play the most complicated concertos, and yet still be unable to play a single note on the violin itself; that is, to have the algorithmic knowledge and not the know-how. Technical treatises are texts that describe gestures, yet words will never be able to explain all the gestures and sensations involved in a technical process. Experimentation forces us to acquire the know-how and to feel the sensations, and these often bring with them important pieces of information on how to read the texts at a deeper and more robust level. Experimentation informs us about what is not said in the texts, about what some authors try desperately to describe, such as Hamdānı̄'s detailed description of colours. This problem of know-how often appears clearly in the texts. In most cases, the authors who described techniques in the Middle Ages were not themselves practitioners, but more often scholars who had been in touch with practitioners, or even who relied only on other texts. This can be observed in Hamdānī's account of cupellation: Hamdānī is a scholar who tries to describe processes that he has probably seen, but never done himself. He omits some very important steps, but describes some parts in an extremely detailed way; he also sometimes describes implausible notions which a practitioner would not have claimed, such as the silver concentration of the ores. This distance between the process and the text is more easily estimated thanks to experimentation, which also underscores the distance between the medieval text and the modern reader.

\section{Acknowledgements}

We would like to thank Hjalmar Fors, Lawrence Principe, Jennifer Rampling, Alan Rocke, and Otto Sibum for their suggestions and their help when reviewing the article. The experimental work could not have been carried out without the help of many students of restoration from the Institut national du patrimoine (INPParis) and the funding of the Institut national de recherches archéologiques préventives (INRAP).

\section{Notes on contributors}

Sébastien Moureau is post-doctoral researcher (Frances A. Yates long-term fellow) at the Warburg Institute, London. His main research interests are the so-called "occult sciences," especially alchemy, in the Arab-Muslim world and their transmission to the Latin world. He has recently published a critical edition of the De anima of pseudo-Avicenna, and in $20 \mathrm{I} 7$ will take up a permanent position as a FNRS researcher at the Université catholique de Louvain, Belgium. Address: Warburg Institute, School of Advanced Study, University of London, UK. Email: sebastien.moureau@uclouvain.be. 
Nicolas Thomas has been an archaeologist at the Institut National de Recherches Archéologiques Préventives (INRAP) for twenty years. He is a research associate at the Laboratoire de médiévistique occidentale de Paris (LAMOP -University Paris I Panthéon-Sorbonne-CNRS-UMR 8589) and has been a lecturer at the Institut National du Patrimoine (metal conservation) and the University Bordeaux 3 (master of archaeometry) for over fifteen years. His main interests are in non-ferrous metallurgy and medieval technology. Address: INRAP, Centre archéologique de Passy, i8 rue de la Chapelle, 895 Io Passy, France. Email: nicolas.thomas@inrap.fr. 